University of Nebraska - Lincoln

DigitalCommons@University of Nebraska - Lincoln

Faculty Papers and Publications in Animal

Science

Animal Science Department

2007

\title{
Comparison of Performance and Economics of a Long-yearling and Calf-fed System
}

\author{
W. A. Griffin \\ University of Nebraska-Lincoln \\ T. J. Klopfenstein \\ University of Nebraska-Lincoln, tklopfenstein1@unl.edu \\ G. E. Erickson \\ University of Nebraska-Lincoln, gerickson4@unl.edu \\ D. M. Feuz \\ Panhandle Research and Extension Center, University of Nebraska, Scottsbluff \\ James C. MacDonald \\ University of Nebraska-Lincoln, jmacdonald2@unl.edu \\ See next page for additional authors
}

Follow this and additional works at: https://digitalcommons.unl.edu/animalscifacpub

Part of the Animal Sciences Commons

Griffin, W. A.; Klopfenstein, T. J.; Erickson, G. E.; Feuz, D. M.; MacDonald, James C.; and Jordon, D. J., "Comparison of Performance and Economics of a Long-yearling and Calf-fed System" (2007). Faculty Papers and Publications in Animal Science. 762.

https://digitalcommons.unl.edu/animalscifacpub/762

This Article is brought to you for free and open access by the Animal Science Department at DigitalCommons@University of Nebraska - Lincoln. It has been accepted for inclusion in Faculty Papers and Publications in Animal Science by an authorized administrator of DigitalCommons@University of Nebraska - Lincoln. 


\section{Authors}

W. A. Griffin, T. J. Klopfenstein, G. E. Erickson, D. M. Feuz, James C. MacDonald, and D. J. Jordon 


\title{
$\pi$ \\ Comparison of Performance and Economics of a Long-yearling and Calf-fed System
}

\author{
W. A. Griffin, ${ }^{*}$ T. J. Klopfenstein, ${ }^{* 2}$ G. E. Erickson, ${ }^{*}$ D. M. Feuz,$\dagger^{3}$ J. C. MacDonald, ${ }^{* 4}$ \\ and D. J. Jordon*5 \\ *Department of Animal Science, University of Nebraska, Lincoln 68583; and †Panhandle Research \\ and Extension Center, University of Nebraska, Scottsbluff 69361
}

\begin{abstract}
Performance and economics of calf feeding and feeding long-yearlings was compared from University of Nebraska research conducted from 1996 to 2004. All calves in these studies were spring born and purchased the subsequent fall. The heaviest calves (292 $\pm 5 \mathrm{~kg})$ were placed into the feedlot and fed an average of 168 d (calf-feds), whereas the lighter calves $(239 \pm 5 \mathrm{~kg})$ were placed into a long-yearling system consisting of corn residue grazing followed by summer grazing before entering the feedlot for finishing. Long-yearlings were fed in the feedlot for an average of $90 \mathrm{~d}$. At the beginning of the finishing period, long-yearlings were $143 \mathrm{~kg}$ heavier than calf-feds $(P<0.01)$. Although daily DMI was greater for long-yearlings $(P<0.01)$, calffeds consumed more total DM during
\end{abstract}

${ }^{1}$ A contribution of the University of Nebraska Agricultural Research Division, supported in part by funds provided through the Hatch Act.

${ }^{2}$ Corresponding author: tklopfenstein1@unl.edu

${ }^{3}$ Current address: Utah State University, 3530 Old Main Hill, Logan, UT 84322.

${ }^{4}$ Current address: West Texas A\&M, 6500 Amarillo Blvd. W., Amarillo, TX 79106.

${ }^{5}$ Current address: Cattlemens Nutrition Services 5900 S. 58th St., Lincoln, NE 68516. finishing $(P<0.01)$. Long-yearlings had greater ADG compared with calf-feds during finishing $(P<0.01)$; however, calffeds were $18.7 \%$ more efficient $(P<$ 0.01). Long-yearlings were $38 \mathrm{~kg}$ heavier $(P<0.01)$ than calf-feds and had $24 \mathrm{~kg}$ heavier hot carcass weight $(P<0.01)$. Quality grade was not affected by production system $(P>0.10)$; however, calffeds had $0.15 \mathrm{~cm}$ greater fat thickness $(P$ $<0.01)$. Long-yearlings were more profitable than calf-feds $(P<0.01)$ due to lower feed cost $(P<0.01)$, yardage $(P$ $<0.01)$, and initial animal cost $(P<$ 0.01). However, long-yearlings had higher interest cost $(P<0.01)$ and total cost $(P=0.02)$. Long-yearlings produced greater final $B W$ leading to an improvement in profitability compared with calffeds.

Key words: calf-fed, long-yearling, production system

\section{INTRODUCTION}

Two major types of postweaning beef cattle production systems include extensive and intensive systems. In extensive systems, cattle are grown in a backgrounding program after weaning using harvested or grazed forage or crop residue through the winter. After wintering, cattle can either enter the feedlot or summer grazing before finishing. The other predominant production system is an intensive system where cattle are weaned and fed a high concentrate diet until slaughter.

The cattle population is diverse in BW and body type (Dolezal et al., 1993). Due to this diversity, it is important to place animals into the correct production system in order to maximize performance and profit potential. Heavier calves may be better suited for intensive finishing systems, which will result in acceptable carcass weights. If larger-framed cattle are placed in extensive production systems, there is potential for these cattle to become too heavy and produce more discounts due to overweight carcasses (Vieselmeyer, 1993). In contrast, lighter, smaller-framed cattle can be grown for a period of time and be slaughtered at a more acceptable weight. These smaller cattle can enter into intensive production systems. However, this leads to lighter carcass weights (Turgeon, 1984) and less profitability because weight is a major economic driver in beef production (Feuz, 2002; Shain et al., 2005; Tatum et al., 2006).

Intensive calf-feeding production systems result in improved feed efficiency, but less weight is sold and more days on feed are required (Turgeon, 1984; Lewis et al., 1989; Jordon, 2000) compared with yearling 
production systems. However, economic comparisons may favor longyearlings based on different marketing times and the differences in total weight sold. Therefore, the objectives of this study were to compare a calfand a yearling-finishing system by analyzing 1) performance and carcass characteristics, 2) economics, and 3) variability in performance measures.

\section{MATERIALS AND METHODS}

The calf- vs. long-yearling system comparison utilized data from both systems at the University of Nebraska from 1996 to 2004. Data used in this project were trials conducted each year except 1997. Animals were received during the fall of each year and sorted by BW. Heavier animals entered an intensive calf-feeding system. Similarly, lighter animals were purchased and entered an extensive long-yearling system. The calf system represented 804 head of steers fed in 80 pens, and the long-yearling system represented 302 head of steers fed in 18 pens. Comparisons were made between calf-feds and the entire long-yearling system (winter, summer, and finishing), and between calf-feds and only the finishing phase of the long-yearling system.

\section{Calf Trials}

Calf trials used for comparison were selected based on the composition of the finishing diet. Finishing diets had to contain a minimum of $25 \%$ wet corn gluten feed (WCGF; Sweet Bran, Cargill, Blair, NE) and a maximum of $40 \%$ WCGF. This range in WCGF inclusion was used to provide a large supply of calves for comparison and because this range has shown minimal differences in finishing performance of steers (Ham et al., 1993; Scott et al., 1997). In each of the calf feeding trials, the control cattle were used to evaluate calf-fed performance. The calf-feds in this study are from Scott et al. (1997, 1999, 2001), Herold et al. (1998), T. Milton, University of Nebraska (personal com- munication), Block et al. (2002), Vander Pol et al. (2003), Macken et al. (2003), Haugen et al. (2004), and Crawford et al. (2006). Calves were purchased in the fall, and following approximately a 21 -d receiving period, were vaccinated, implanted, and placed on feed until slaughter, which occurred between late April and early May. Calf-feds were reimplanted approximately $100 \mathrm{~d}$ prior to slaughter in each experiment.

\section{Long-yearling Trials}

After purchase, steers were vaccinated and grazed cornstalks from December 1 until April 20 following approximately a 21 -d receiving period. During the wintering period, steers were supplemented with $2.27 \mathrm{~kg} /$ steer daily of WCGF to achieve a minimum gain of $0.68 \mathrm{~kg} / \mathrm{d}$ (Jordon, 2000). After the wintering period, steers were implanted with Revalor-G (Intervet, Millsboro, DE) and grazed brome grass (Bromus inermis) pasture until the middle of May. They were then relocated to graze Sandhills range grasses for the remainder of the summer grazing period until September. After completion of the summer grazing period, steers were implanted, placed in the feedlot, and fed until slaughter. The finishing diet contained $40 \%$ WCGF and $45 \%$ of either dry rolled or high moisture corn (DM basis) depending on the year. As with the calf-feds, the cattle on the control treatment from the long-yearling studies were used to make comparisons between long-yearlings and calf-feds. The average month of slaughter for long-yearling cattle was December. Long-yearling trials used in this study included Downs et al. (1998), Jordon (2000), Folmer (2004), MacDonald et al. (2006), and Griffin et al. (2007).

\section{Economic Analysis}

Initial animal price in both systems was determined using a slide of $\$ 3.20 / 45 \mathrm{~kg}$ and the USDA 1998 to 2004 average December feeder cattle price of $\$ 98.98 / 45 \mathrm{~kg}$ for a $273 \mathrm{~kg}$ steer (Feuz, 2004). The average De- cember price was determined by averaging the price of $250 \mathrm{~kg}$ steers (\$102.97/45 kg; Feuz, 2004) and 295 $\mathrm{kg}$ steers (\$94.98/45 kg; Feuz, 2004). The price slide was determined from the actual purchase prices for cattle purchased by the University of Nebraska from 2000 to 2005. After determining the average December price for a $273 \mathrm{~kg}$ steer, the slide was used to adjust the price paid for the steers using BW of the steers at receiving. An additional analysis was used to determine the profitability of buying or retaining steers through each phase of the long-yearling production system. A price of $\$ 105.06 / 45 \mathrm{~kg}$ for $318 \mathrm{~kg}$ steers (Feuz, 2004) was used to determine the value of the steers when they were removed from corn stalks. The slide for $318 \mathrm{~kg}$ to $364 \mathrm{~kg}$ steers in April was determined to be $\$ 7.26 / 45 \mathrm{~kg}$ and was used to calculate animal value at the end of the stalk grazing period. At the end of the summer grazing period, steer value was determined using the September price for a $409 \mathrm{~kg}$ steer $(\$ 86.10 / 45 \mathrm{~kg}$; Feuz, 2004) and a price slide of $\$ 4.74 / 45 \mathrm{~kg}$. In both systems, 2 percent death loss was assumed; however, in the calf-feds the death loss was charged at the beginning of the finishing period and the long-yearling death loss was calculated by using $1.5 \%$ death loss in the winter phase, $0.3 \%$ death loss in the summer phase, and $0.2 \%$ death loss in the finishing phase.

\section{Calf Finishing Economics}

Calf-finishing slaughter breakevens were calculated on pens of cattle from each of the respective trials. Initial animal cost was determined using the average price $/ \mathrm{kg}(\$ 97.37 / 45 \mathrm{~kg})$ multiplied by BW. Interest was applied to initial cost of the animal over the entire ownership. The interest rate used was determined using the 7-yr average prime interest rate plus $1 \%$ for the months that the cattle were owned (6.6\%). Health, processing, and implanting were assessed at a rate of $\$ 16.66 /$ steer. Feed cost for calf-feds was based on 7-yr average 
price of ingredients for the months that ingredients were fed. Wet corn gluten feed was priced at $95 \%$ of the price of corn (Erickson et al., 2005) using the 7-yr average price for corn. The average ration cost for calf-fed diets was $\$ 114.71 /$ metric ton on a DM basis. Average DMI for each pen was used to determine total feed consumption during the finishing period. Yardage was charged at a rate of $\$ 0.33 /$ steer daily. Interest was charged on half of the finishing diet and yardage of the feeding period. To calculate slaughter breakeven, total cost was divided by slaughter BW. Slaughter BW was determined using hot carcass weight divided by a common dressing percent of $63 \%$.

\section{Long-yearling Economics}

Initial steer cost was determined using the average price per kilogram $(\$ 101.44 / 45 \mathrm{~kg})$ multiplied by BW. Health and processing were assessed at $\$ 8.33 /$ steer for the winter period. Simple interest was assessed on initial animal cost and health for the entire period of ownership using the 7-yr average prime interest rate plus $1 \%$ (6.6\%).

The cost of corn residue grazing was determined at a rate of $\$ 0.32 /$ steer daily. This cost includes $\$ 0.12$ / steer for the rent of cornstalk residue and $\$ 0.20 /$ steer charged as yardage. The yardage cost includes the cost of fencing stalk fields and cost of labor to deliver WCGF. Steers were supplemented with $2.27 \mathrm{~kg} /$ steer daily (DM basis) of WCGF for the entire winter period at a cost of $\$ 92.62 /$ metric ton (DM basis). This price is equal to 95\% the price of corn (Erickson et al., 2005) when corn is $\$ 0.084 / \mathrm{kg}$ (as-is). Interest was charged on half of the stalks, yardage, and WCGF fed during the winter period.

Summer grazing cost was determined using the 7-yr average animal unit month (AUM) value of $\$ 23.29$ for native range. An AUM is defined as the amount of forage an animal unit consumes in $30 \mathrm{~d}$ (Reece et al., 2001). Typically, a $454-\mathrm{kg}$ animal is considered to be one animal unit (Re- ece et al., 2001). To determine the animal unit equivalent of the steers used in this study, the average grazing BW of the cattle was divided by $454 \mathrm{~kg}$. To determine the total AUM during summer grazing, the number of days was divided by 30 and multiplied by the animal unit equivalent. The AUM usage was then multiplied by the AUM value to determine the cost of native range during summer grazing. Cattle were assessed $\$ 8.33 /$ steer for summer health costs, and interest was charged for the cost of grazing using prime plus $1 \%$ for the cost of the AUM and health cost.

Finishing costs for long-yearlings were similar to calf-feds using the same daily yardage rate of $\$ 0.33 /$ steer. Feed ingredients were priced using the 7-yr average for ingredients the month they were fed. The average cost of the long-yearling diet was $\$ 105.69 /$ metric ton. Average DMI for each pen was used to determine total feed consumption during the finishing period. Interest was charged on half of the finishing diet and yardage for the feeding period. To calculate slaughter breakeven, total cost was divided by slaughter BW.

Profit was calculated 2 ways, first using 7-yr average live price for the month of May (calf-fed; $\$ 72.68 / 45$ $\mathrm{kg}$ ) and December (long-yearling; $\$ 74.23 / 45 \mathrm{~kg}$ ) and subtracting the total cost of production from the value of the animal. Second, profit was calculated by selling cattle in the beef using a value-based market that rewards for carcass quality. The grid was calculated using $2 \mathrm{yr}$ of grid prices from the plant where the cattle were sold and averaging the premiums and discounts received for the carcasses. The grid is presented in Table 1. The base for this grid was a carcass with a minimum QG of choice ${ }^{0}$ and YG 3 carcass. The base price used for the steer was the average Nebraska carcass beef price for a USDA YG 3, choice ${ }^{0}$ for calf-feds in May (\$120.69; Feuz, 2004) and long-yearlings in December (\$121.52; Feuz, 2004) from 1998 to 2004. This price was calculated using the Nebraska Dressed Price (1998 to
2004) adjusted by adding the sum of one minus the average Choice grading percent for the month of May for calf-feds and December for long-yearlings multiplied by the choice-select spread for the month of May and December.

\section{Variation Analysis}

Variation in beef can cause serious losses to the beef industry (Boleman et al., 1998). Therefore, it is important to understand the amount of variation that exists in cattle between the calf-fed and long-yearling system. To determine the differences in carcass uniformity, the standard deviation for receiving $\mathrm{BW}$, feedlot initial BW, final BW, hot carcass weight, USDA marbling score, USDA YG, and fat thickness were analyzed. Analysis was performed using a log 10 transformation of the standard deviation of the means of the experimental units (Kuehl, 2000).

\section{Comparison at Equal Fat Endpoints}

When comparing cattle of different types or treatments it is important to compare cattle at equal fat points (Tedeschi et al., 2004). Bruns et al. (2004) reported fattening rate for calffeds to be quadratic. However, cattle were fed for $250 \mathrm{~d}$ with the objective of producing cattle beyond average commercial fat endpoints. In the current study, calf-feds were fed for 168 $\mathrm{d}$ and the fat end point was similar to the cattle slaughtered at $187 \mathrm{~d}$ in the work by Bruns et al. (2004). Using data from Bruns et al., (2004), the regression line does not show a quadratic effect until cattle are fed longer than $187 \mathrm{~d}$. Therefore, in adjusting this data set, it would be appropriate to use linear regression. When determining fattening rate for long-yearlings, May et al. (1992) observed a linear response for long-yearling steers through the entire finishing period. Therefore, to determine fattening rate, 2 regression equations from May et al. (1992) and Bruns et al. (2004) were used to estimate the initial fat 
Table 1. Premiums and discounts for grid market analysis

\begin{tabular}{lrc} 
Item, \$/45 kg & Calf-fed $^{{ }^{1}}$ & Long-yearling $^{2}$ \\
\hline Prime & 8.00 & 8.00 \\
Upper Choice & 3.00 & 6.00 \\
Choice & 0.00 & 0.00 \\
Select & -9.01 & -8.10 \\
Standard & -10.50 & -15.00 \\
YG 1 & 8.00 & 3.00 \\
YG 2 & 4.00 & 3.00 \\
YG 3 & 0.00 & 0.00 \\
YG 4 & -10.00 & -10.00 \\
YG 5 & -15.00 & -17.49 \\
Carcass weight $>$ 432 kg & -10.00 & -10.00 \\
Carcass weight $>455 \mathrm{~kg}$ & -20.00 & -20.00 \\
& & \\
${ }^{1}$ Average market month for calf-fed was May. & \\
${ }^{2}$ Average market month for long-yearling was December.
\end{tabular}

thickness and tested using the Proc Reg function of SAS (SAS Inst., Inc., Cary, NC) to determine if the intercepts were different. The intercepts were numerically different $(P=0.07)$; therefore, the intercept from Bruns et al. (2004) of $0 \mathrm{~cm}$ was used for calffeds and the intercept from May et al. (1992) of $0.208 \mathrm{~cm}$ was used for long-yearlings. The initial fat thickness was subtracted from the final fat thickness and divided by days fed to determine a fattening rate for each animal. Using the calculated fattening rate, days on feed were adjusted by subtracting the initial fat thickness from a fat thickness of $1.27 \mathrm{~cm}$ to determine the number of days it would take an animal to achieve a fat thickness of $1.27 \mathrm{~cm}$. The initial feedlot carcass weight of each animal was determined using the initial feedlot BW of each animal and adjusting to a $55 \%$ dressing percent (May et al., 1992; Bruns et al., 2004). Initial carcass weight was subtracted from the actual carcass weight of the animal and divided by the number of days fed to determine the daily carcass gain of each animal. This procedure was used by MacDonald et al. (2007) who demonstrated that carcass gain remains constant over the entire finishing period. Also the marbling rate for long-yearlings and calf-feds was determined using the intercepts from
2 regression equations for marbling deposition. For long-yearlings, data from May et al. (1992) were used and data from Bruns et al. (2004) were used for calf-feds. The Proc Reg function of SAS was used to determine if the intercepts for these 2 regression equations were different. The intercepts were not different $(P=0.14)$; therefore, the 2 intercepts were averaged to determine the animal's initial marbling score at feedlot entry (324; marbling score of $400=$ slight $^{0}, 500=$ small $^{0}$, etc.). Initial marbling score was subtracted from the final marbling score and divided by days fed to determine the marbling rate of each pen of cattle.

Adjusted carcass weight was calculated by multiplying the adjusted days fed by the carcass rate of gain and adding the initial carcass weight of the animal at feedlot entry. Similarly, marbling score was adjusted by multiplying the marbling rate by the adjusted days fed and adding this to the initial marbling score of 324 .

\section{Statistical Analysis}

Data from this study were analyzed as a completely randomized design using the mixed procedure of SAS. Additionally, feedlot pen was the experimental unit. The model included production system as a fixed effect and year and year $\times$ treatment as random variables. Least square means were separated using the least significant difference method when a significant $(P<0.05)$ treatment $F$-test was detected.

\section{RESULTS AND DISCUSSION}

\section{Animal Performance}

At receiving, calf-feds were $52 \mathrm{~kg}$ heavier $(P<0.01)$ than steers entering the long-yearling system (Table 2). However, when comparing calf-feds to long-yearlings at feedlot entry, the long-yearlings were $144 \mathrm{~kg}$ heavier $(P$ $<0.01)$ than calf-feds because the long-yearlings had been grown. The increase in initial feedlot BW led to a $38 \mathrm{~kg}$ heavier $(P<0.01)$ final BW for long-yearling cattle compared with calf-feds. Long-yearlings consumed more DM per day $(P<0.01)$ compared with calf-feds; however, calffeds consumed $381 \mathrm{~kg}$ more total DM $(P<0.01)$ during the finishing period compared with long-yearlings. The increase in total DM was because calffeds were fed $78 \mathrm{~d}$ longer $(P<0.01)$ than long-yearlings. Long-yearlings had $0.33 \mathrm{~kg}$ greater $(P<0.01)$ ADG than calf-feds; however, calf-feds had a $18.7 \%$ greater $\mathrm{G}: \mathrm{F}(P<0.01)$ than long-yearlings.

Saubidet and Verde (1976) determined that as animal age increases, so does DMI. The authors speculated that animal age likely had a greater influence on DMI than BW. In our study, long-yearlings were approximately $200 \mathrm{~d}$ older than calf-feds at slaughter.

Composition of gain also offers some explanation of why calf-feds were more efficient than long-yearlings. Long-yearlings fattened at a faster rate than calf-feds $(P<0.01$; Table 3). This is because the long-yearlings have achieved much of their skeletal growth and muscle accretion during the growing phase of the long-yearling system. This difference in efficiency is because it takes less energy to gain $1 \mathrm{~kg}$ of muscle than $1 \mathrm{~kg}$ of fat (NRC, 1996). 
Table 2. Effects of calf-fed or long yearling production system on animal performance

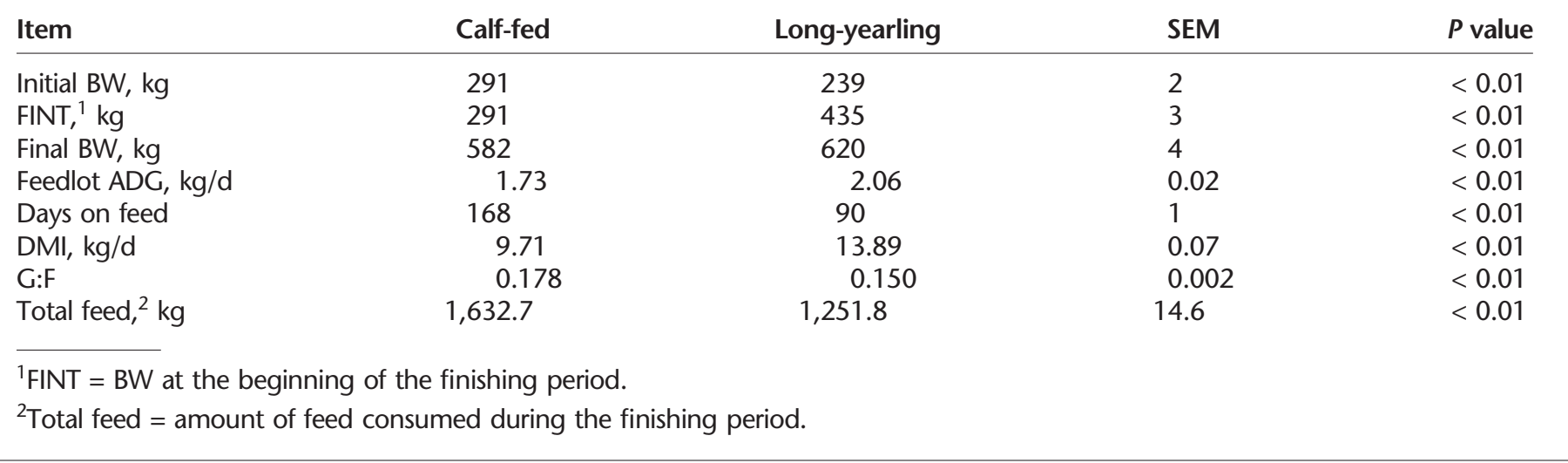

\section{Carcass Characteristics}

Carcass characteristics of long-yearlings and calf-feds are presented in Table 4 . When comparing hot carcass weights, long-yearlings were $24 \mathrm{~kg}$ heavier than calf-feds $(P<0.01)$. Calffeds had $0.15 \mathrm{~cm}$ greater fat thickness $(P<0.01)$ compared with long-yearlings; however, marbling was not different $(P=0.21)$ between production systems. There was no difference in the percentage of animals grading choice or higher $(P=0.13)$ or USDA YG $(P=0.46)$. Calf-feds produced 8.6 percentage units more USDA YG 4 carcasses than long-yearling steers $(P=0.11)$. However, long-yearlings produced 10.2 percentage units more overweight carcasses compared with calf-feds $(P=0.02)$.

Several reports have shown that backgrounded steers produce heavier carcasses (Jordon, 2000; Krehbiel et al., 2000; Sainz and Vernazza Paganini, 2004) compared with cattle placed directly on feed after weaning. Sainz and Vernazza Paganini (2004) found similar results to this trial showing that long-yearlings and calf- feds had similar marbling score, USDA YG, and percent of carcasses grading choice or higher. Conversely, when cattle of similar type are placed into different production systems, long-yearlings tend to be leaner and have lesser quality carcasses at harvest when compared with calf-feds (Schoonmaker et al., 2002; Anderson et al., 2003). The similarity in the fat thickness and QG in the current study can be attributed to the fact that cattle were allotted to production system based on body type. Calffeds in the current study were heavier

Table 3. Effects of calf-fed or long-yearling production systems on rates of deposition and steer performance adjusted to constant rib fat thickness

\begin{tabular}{|c|c|c|c|c|}
\hline Item & Calf-fed & Long-yearling & SEM & $P$ value \\
\hline \multicolumn{5}{|l|}{ Rates of deposition } \\
\hline Carcass gain, kg/d & 1.23 & 1.69 & 0.10 & $<0.01$ \\
\hline Marbling rate, ${ }^{1}$ points/d & 1.13 & 2.17 & 0.10 & $<0.01$ \\
\hline Rib fat rate, ${ }^{2} \mathrm{~cm} / \mathrm{d}$ & 0.0081 & 0.0111 & 0.0002 & $<0.01$ \\
\hline \multicolumn{5}{|l|}{ Actual carcass measures } \\
\hline Fat thickness, cm & 1.35 & 1.20 & 0.03 & $<0.01$ \\
\hline Carcass weight, $\mathrm{kg}$ & 367 & 390 & 2 & $<0.01$ \\
\hline Days on feed & 168 & 90 & 1 & $<0.01$ \\
\hline Marbling score $^{3}$ & 510 & 525 & 10 & 0.21 \\
\hline \multicolumn{5}{|c|}{ Rib fat thickness adjusted to $1.27 \mathrm{~cm}$} \\
\hline Adjusted carcass weight, kg & 355 & 422 & 26 & $<0.01$ \\
\hline Adjusted days on feed & 158 & 96 & 10 & $<0.01$ \\
\hline Adjusted marbling score & 503 & 533 & 12 & 0.04 \\
\hline
\end{tabular}

${ }^{1}$ Adjusted days on feed in the number of days in the finishing period it takes a long-yearling or calf-fed to achieve a rib fat thickness of $1.27 \mathrm{~cm}$.

${ }^{2}$ Rib fat rate $=$ rate at which back fat was deposited.

${ }^{3}$ Marbling score: $400=$ slight $^{0}, 500=$ small $^{0}$, etc. 
Table 4. Effects of calf-fed or long-yearling production system on carcass characteristics

\begin{tabular}{lcccr} 
Item & Calf-fed & Long-yearling & SEM & $P$ value \\
\hline Carcass weight, kg & 367 & 390 & 2 & $<0.01$ \\
Fat thickness, cm & 1.35 & 1.20 & 0.03 & $<0.01$ \\
YG & 2.71 & 2.60 & 0.14 & 0.46 \\
Marbling score $^{1}$ & 510 & 525 & 9.9 & 0.21 \\
\% Choice & 58.4 & 65.0 & 3.8 & 0.13 \\
\% YG 4+ & 11.9 & 3.3 & 4.7 & 0.11 \\
\% carcasses $>$ 432 kg & 1.1 & 11.3 & 3.5 & 0.02 \\
\% carcasses $>$ 454 kg & 0.4 & 3.2 & 1.5 & 0.09
\end{tabular}

${ }^{1}$ Marbling score: $400=$ slight $^{0}, 500=$ small $^{0}$, etc.
The increase in profitability was because long-yearlings produced more weight at the end of the production period and less YG 4 carcasses, and because QG was similar to calf-feds. Lewis et al. (1990) found similar results for slaughter breakeven when cattle were finished as calves compared with a long-yearling-finishing program. Lewis et al. (1990) also reported that summer grazing was the most cost efficient way for cattle to gain weight. However, in today's market this may not be the case with the increasing cost of grass on an AUM basis compared with corn or corn byproducts and the gain response to those products (Morris et al., 2006). Tatum et al. (2006) reported that carcass weight was the single most important driver of carcass value per head, leading to increased profitability for cattle with heavier carcasses. Jordon (2000) and Shain et al. (2005) reported that slaughter BW was the largest determining factor in terms of both slaughter breakeven and profitability and accounted for 21 to $30 \%$ of the variation, respectively. From the current study, when costs of gain are similar across production systems and $\mathrm{BW}$ is the major driver of profitability (Feuz, 2002; Shain et al., 2005; Tatum et al., 2006), long-yearlings produced a more profitable final product.

Perhaps the biggest factor affecting profitability of a long-yearling production system is the decision to either sell cattle at the end of each production phase or to retain ownership through the entire production system. If steers were sold when they were removed from corn crop residue, they would have produced profit of $\$ 129.18$ (Table 6). The wintering system utilized in this long-yearling system research was economical because 1) corn residue is relatively abundant and inexpensive, 2) WCGF at $95 \%$ the price of corn is an economical protein, energy, and phosphorus supplement, and 3) yardage cost is relatively low. If long-yearling steer ownership was retained and steers were sold at the end of summer 
Table 5. Economic analysis of calf-fed and long-yearling production system

\begin{tabular}{|c|c|c|c|c|}
\hline Item & Calf-fed & Long-yearling & SEM & $P$ value \\
\hline Steer cost, $\$$ & 627.60 & 533.54 & 5.11 & $<0.01$ \\
\hline Wintering cost, $\$ /$ steer & - & 78.72 & - & - \\
\hline Summer cost, $\$ /$ steer & - & 90.10 & - & - \\
\hline Interest, ${ }^{1} \$ /$ steer & 23.68 & 48.14 & 1.01 & $<0.01$ \\
\hline Feed cost, $\$ /$ steer & 188.34 & 133.71 & 6.54 & $<0.01$ \\
\hline Yardage, \$/steer & 55.58 & 29.78 & 1.90 & $<0.01$ \\
\hline Death loss, $\$ /$ steer & 13.43 & 13.74 & 0.10 & 0.02 \\
\hline Total cost, \$/steer & 924.18 & 943.81 & 6.89 & 0.02 \\
\hline $\mathrm{COG}_{,}^{2,3} \$ / 45 \mathrm{~kg}$ & 49.86 & 49.12 & 1.42 & 0.61 \\
\hline Breakeven, ${ }^{3} \$ / 45 \mathrm{~kg}$ & 72.19 & 69.23 & 1.12 & 0.04 \\
\hline Live value, ${ }^{4} \$ /$ steer & 932.28 & $1,012.91$ & 19.26 & $<0.01$ \\
\hline Grid value, ${ }^{5} \$ /$ steer & 955.19 & $1,017.72$ & 15.95 & $<0.01$ \\
\hline \multicolumn{5}{|l|}{ Retained ownership ${ }^{6}$} \\
\hline Live p/l, $\$ /$ steer & 7.77 & 68.95 & 15.43 & $<0.01$ \\
\hline Grid $\mathrm{p} / \mathrm{l}^{7} \$ /$ steer & 30.61 & 73.66 & 10.59 & $<0.01$ \\
\hline \multicolumn{5}{|l|}{ Bought at feedlot entry ${ }^{8}$} \\
\hline Live $p / l, \$ /$ steer & 7.77 & 16.87 & 13.52 & 0.49 \\
\hline Grid $\mathrm{p} / \mathrm{l}, \$ /$ steer & 30.61 & 24.99 & 12.50 & 0.53 \\
\hline \multicolumn{5}{|c|}{${ }^{1}$ Interest is the total amount of interest accrued from the animal and all cost of production. } \\
\hline \multicolumn{5}{|c|}{${ }^{2} \mathrm{COG}=$ cost of gain for the entire production system. } \\
\hline \multicolumn{5}{|c|}{${ }^{3}$ All prices on a per $45 \mathrm{~kg}$ live-basis. } \\
\hline \multicolumn{5}{|c|}{${ }^{4}$ Live sale price of $\$ 74.23 / 45 \mathrm{~kg}$ long-yearlings and $\$ 72.68 / 45 \mathrm{~kg}$ for calf-feds. } \\
\hline \multicolumn{5}{|c|}{${ }^{5}$ Carcass base price of $\$ 121.52 / 45 \mathrm{~kg}$ for long-yearlings and $\$ 120.69 / 45 \mathrm{~kg}$ for calf-feds. } \\
\hline \multicolumn{5}{|c|}{${ }^{6}$ Profit comparison if long-yearling ownership is retained through the entire production system. } \\
\hline${ }^{7} \mathrm{p} / \mathrm{l}=$ profit or loss. & & - & & \\
\hline${ }^{8}$ Profit comnarison if & & & & \\
\hline
\end{tabular}

grazing, profit would be reduced to $\$ 54.93$. However, if a producer purchased steers when removed from cornstalks and placed them in a sum- mer grazing program, steers would lose $\$ 81.44$. This difference in profitability is due to the amount of weight purchased at the beginning of

Table 6. Economic comparison of retained ownership through each phase of production in a long-yearling production system

\begin{tabular}{lcr} 
Item & Bought $^{1}$ & Retained $^{2}$ \\
\hline $\begin{array}{l}\text { Long-yearling growing phases } \\
\text { Winter, \$/steer }\end{array}$ & 129.18 & \\
Summer, \$/steer & -81.44 & 129.18 \\
Long-yearling finishing phase & & 54.93 \\
Live basis, \$/steer & 16.87 & 68.45 \\
Grid basis, \$/steer & 24.99 & 76.57
\end{tabular}

${ }^{1}$ Bought prices are profit or loss of each part of the long-yearling system if calves were bought at the beginning and sold at the end of each phase of production. ${ }^{2}$ Retained prices are profit or loss of each part of the long-yearling system if calves were bought at the beginning of the wintering period and sold at the end of each phase of production.

summer grazing and the low rate of gain relative to the value of summer grass. When entering into the finishing period, steers that were retained through the entire production system had profits of $\$ 68.45$ when sold on a live basis and $\$ 76.57$ when sold on the grid. If long-yearling steers were purchased at the beginning of the finishing period instead of being retained through the entire system, they would have a profit of $\$ 16.87$ live and $\$ 24.99$ on the grid. When comparing long-yearlings that are purchased at the beginning of the finishing period to calf-feds, there is no difference in profitability $(P>0.49$; Table 5). When looking at the entire production system of long-yearling steers, low cost inputs during the winter phase of the production system were the major source of profitability in this long-yearling production system. 
There are several different variables that can have major impacts on the profitability of both calf-feds and long-yearling production systems. Perhaps the variables that will have the largest impact on profitability are feedlot yardage for long-yearlings and calf-feds, cost of grass during summer grazing for long-yearlings, and costs for shipping long-yearlings to cornstalks and summer grazing. A $\$ 0.05 / \mathrm{d}$ increase in yardage reduces profitability of calf-feds and long-yearlings $\$ 8.40$ and $\$ 4.50$, respectively, when using their respective days fed. The increase in yardage would increase the profitability difference between calffeds and long-yearlings from a profit advantage of $\$ 43.05$ to $\$ 46.95$ for long-yearlings when selling on a value based grid. If grass costs were to increase, the difference in profitability between calf-feds and long-yearlings would decrease. For every \$1.00/AUM increase, profitability for long-yearling steers decreases $\$ 3.87 /$ steer because steers consumed an average of 3.87 AUM during the summer grazing period. This long-yearling system is based on the use of corn residue. For many producers, it may be necessary to transport the long-yearlings to pasture and return them to a feedlot for finishing. Using a per steer cost of $\$ 0.08 /$ loaded mile, producers could haul cattle a total of 269 miles before profitability of long-yearlings would be equal to calf-feds. Typically, feedlots and corn residues are in close proximity. Sufficient pasture may require hauling to and from the pasture for the cattle owner.

\section{Variation Analysis}

Initial BW for long-yearlings exhibited an $8.5 \mathrm{~kg}$ greater variation $(P=$ $0.02)$ than calf-feds at receiving (Table 7). The variation remained consistent, with long-yearlings exhibiting $18.1 \mathrm{~kg}(P<0.01)$ and $15.3 \mathrm{~kg}(P<$ $0.01)$ more variation in feedlot initial and final BW, respectively, compared with calf-feds. When comparing variation in carcass characteristics, longyearlings were $9.7 \mathrm{~kg}$ more variable in hot carcass weight $(P<0.01)$ compared with calf-feds. However, variation in fat thickness $(P=0.41)$, marbling score $(P=0.84)$, and YG $(P=$ 0.31 ) were not different between long-yearlings and calf-feds.

The higher variation at receiving for long-yearlings compared with calf-feds was surprising because cattle tend to grow apart over the growing or finishing period (MacDonald et al., 2006). However, because calf-feds were sorted at receiving from a larger pool of animals, the variation in BW of calf-feds at initiation of finishing was reduced compared with long-yearlings. The increase in variation for long-yearlings compared with calffeds later in the growing and finishing periods was expected due to the greater length of the production system for long-yearlings compared with calf-feds (MacDonald et al., 2006)

\section{Comparisons at Equal Body Fat}

The rate of back fat deposition was $37 \%$ faster for long-yearlings compared with calf-feds $(P<0.01$; Table $3)$. This difference in fat deposition rate resulted in 62 fewer $(P<0.01)$ adjusted days fed in order for long-yearlings to achieve a fat thickness of $1.27 \mathrm{~cm}$. Due to the heavier initial carcass weight and the higher rate of carcass gain for long-yearlings, fat adjusted carcass weight was $67 \mathrm{~kg}$ heavier $(P<0.01)$ for long-yearlings compared with calf-feds. Long-yearlings had a 30.2 point higher $(P<0.01)$ adjusted marbling score than calf-feds when compared at equal fat thickness because of the increased marbling rate for long-yearlings when long-yearlings and calf-feds entered the finishing period with the same degree of marbling.

In order to determine true biological differences of animals in the 2 different production systems, it is important to evaluate the animals at equal fatness. The marbling rate for long-yearlings was similar to the marbling rate reported by Vieselmeyer et al. (1995), who found that long-yearling cattle deposit intramuscular fat approximately 2 times faster than calf-feds. Vieselmeyer et al. (1995) found that long-yearlings and calffeds had similar rates of subcutaneous fat deposition. However, in the current study, long-yearlings deposited fat at a faster rate than calf-feds. Per-

Table 7. Standard deviation of weights and carcass characteristics of calf-feds and long-yearling steers ${ }^{1}$

\begin{tabular}{|c|c|c|c|c|}
\hline Item & Calf-fed & Long-yearling & SEM & $P$ value \\
\hline Initial BW, kg & 10.29 & 18.80 & 0.56 & 0.02 \\
\hline $\mathrm{FINT}^{2} \mathrm{~kg}$ & 10.29 & 28.35 & 0.57 & $<0.01$ \\
\hline Final BW, kg & 30.26 & 45.56 & 0.51 & $<0.01$ \\
\hline Carcass weight, kg & 19.04 & 28.75 & 0.51 & $<0.01$ \\
\hline Fat thickness, $\mathrm{cm}$ & 2.74 & 2.79 & 2.87 & 0.41 \\
\hline YG & 0.63 & 0.57 & 1.09 & 0.31 \\
\hline Marbling score ${ }^{3}$ & 60.6 & 59.4 & 1.1 & 0.84 \\
\hline
\end{tabular}

\footnotetext{
${ }^{1}$ Statistical analysis based on log base 10 of standard deviation. Values reported are transformations from log base 10 values. ${ }^{2}$ FINT = BW at the beginning of the finishing period.

${ }^{3}$ Marbling score: $400=$ slight $^{0}, 500=$ small $^{0}$, etc.
} 
haps the reason for the differing rates in fat deposition can be explained by the difference in calculations of the rates. Vieselmeyer et al. (1995) measured the rate of fat deposition using early slaughter and a late slaughter groups. Therefore, the rate of fat deposition was calculated for the last $66 \mathrm{~d}$ on feed for the calf-feds and the last $21 \mathrm{~d}$ on feed for the long-yearlings. However, the rates in the current study are for the entire feeding period and not limited to the end of the finishing period.

Klopfenstein et al. (2000) found that long-yearlings are not finished to the same degree of rib fat thickness when compared with calf-feds. When adjusting the long-yearlings to a similar fat thickness as the calf-feds, Klopfenstein et al. (2000) found that longyearlings produced a 19.3 percentage unit increase in choice carcasses compared with calf-feds. However, longyearling cattle must be sold with less fat cover compared with calf-feds because of the risk of producing overweight carcasses (Klopfenstein et al., 2000).

The greater carcass gain for the long-yearlings was expected given the greater ADG of long-yearlings compared with calf-feds. Calf-feds require more days on feed to achieve a QG of choice and achieve an acceptable carcass weight; however, calf-feds are at risk of producing more USDA YG 4 carcasses compared with long-yearlings that require fewer days to achieve a choice QG but are at risk of producing overweight carcasses.

\section{IMPLICATIONS}

Long-yearlings have an advantage in feedlot performance due to the increased gain and less total feed consumed during the finishing period. However, long-yearlings require more days of ownership in order to reach harvest. Even though calf-feds may gain more efficiently, light calves managed in a growing-finishing system and retained through the entire production system may have lower breakevens and may potentially be more profitable than calf-feds. If long-yearlings are purchased at feedlot entry, there is no difference in profitability between long-yearlings and calf-feds. Calf-feds tend to get too fat and long-yearlings tend to get too heavy. When comparing the animals at equal fat thickness, long-yearlings gain faster and deposit intramuscular fat faster, allowing for fewer days on feed to produce a quality carcass.

\section{LITERATURE CITED}

Anderson, R., R. Rasby, T. Klopfenstein, and C. Macken. 2003. Evaluation of cow and calf performance and profit potential in beef systems. Nebraska Beef Rep. MP 80-A:3.

Block, H., C. Macken, T. Klopfenstein, R. Cooper, and R. Stock. 2002. Crude protein and wet corn gluten feed levels for steam flaked corn finishing diets. Nebraska Beef Rep. MP 79-A:68.

Boleman, S. L., S. J. Boleman, W. W. Morgan, D. S. Hale, D. B. Griffin, J. W. Savell, R. P. Ames, M. T. Smith, J. D. Tatum, T. G. Field, G. C. Smith, B. A. Gardner, J. B. Morgan, S. L. Northcutt, H. G. Dolezal, D. R. Gill, and F. K. Ray. 1998. National beef quality audit-1995: Survey of producer-related defects and carcass quality and quantity attributes. J. Anim. Sci. 76:96.

Bruns, K. W., R. H. Pritchard, and D. L. Boggs. 2004. The relationships among body weight, body composition, and intramuscular fat content in steers. J. Anim. Sci. 82:1315.

Crawford, G. I., G. E. Erickson, K. J. Vander Pol, M. A. Greenquist, J. D. Folmer, and M. T. Van Koevering. 2006. Effect of Optaflexx dosage and duration of feeding prior to slaughter on feed conversion and carcass characteristics. Nebraska Beef Rep. MP 88-A:72.

Dolezal, H. G., J. D. Tatum, and F. L. William, Jr. 1993. Effects of feeder cattle frame size, muscle thickness, and age class on days fed, weight, and carcass composition. J. Anim. Sci. 71:2975

Downs, D., G. Erickson, D. Adams, and T. Klofenstein. 1998. Effect of winter gain on summer rate of gain and finishing performance of yearling steers. Nebraska Beef Rep. MP 69A:63.

Erickson, G. E., T. J. Klopfenstein, K. J. Vander Pol, V. R. Bremer, and P. L. Loza. 2005. Feeding wet corn milling byproducts to beef cattle. Proc. 66th MN Nutr. Conf., St. Paul, MN.

Feuz, D. M. 2002. A simulated market analysis of altering days on feed and marketing cattle on specific value-based pricing grids. Nebraska Beef Rep. MP 79-A:39.

Feuz, D. M. 2004. Feuz market analysis. http://www.panhandle.unl.edu/feuz/ index.html Accessed January 4, 2006.
Folmer, J. D. 2004. Effects of intensive winter management, partial season grazing, and sorting by feedlot in weight on performance and economics of yearling steer performance. PhD. Dissertation, Univ. of Nebraska, Lincoln.

Griffin, W. A., T. J. Klopfenstein, G. E. Erickson, D. M. Feuz, K. J. Vander Pol, and M. A. Greenquist. 2007. Effect of sorting and Optaflexx supplementation on feedlot performance and profitability of long yearling steers. Nebraska Beef Rep. MP 90:58.

Ham, G., R. Huffman, R. Stock, and T. Klopfenstein. 1993. Wet gluten feed in beef diets. Nebraska Beef Rep. MP 59-A:46.

Haugen, H. L., G. E. Erickson, C. G. Cambell, and C. N. Mackan. 2004. Influence of implant regimen on performance and carcass characteristics in feedlot steers. Nebraska Beef Rep. MP 80-A:36.

Herold, D., M. Klemersrud, T. Klopfenstein, T. Milton, and R. Stock. 1998. Solvent-extracted germ meal, corn bran and steep liquor blends for finishing steers. Nebraska Beef Rep. MP 69A:50.

Jordon, D. J. 2000. Performance and slaughter breakeven analysis of calf and yearling systems and compensatory growth. PhD Dissertation, Univ. of Nebraska, Lincoln.

Klopfenstein, T., R. Cooper, D. J. Jordon, D. Shain, T. Milton, C. Calkins, and C. Rossi. 2000. Effects of backgrounding and growing programs on beef carcass quality and yield. Proc. Am. Soc. Anim. Sci., 1999. http://www.asas.org/JAS/symposia/proceedings/0942.pdf Accessed January 08, 2007.

Krehbiel, C. R., K. K. Kreikemeier, and C. L. Ferrell. 2000. Influence of Bos indicus crossbreeding and cattle age on apparent utilization of a high grain diet. J. Anim. Sci. 78:1641.

Kuehl, R. O. 2000. Design of Experiments: Statistical Principles of Research Design and Analysis. p 123. Brooks/Cole Publishing Co., Pacific Grove, CA.

Lewis, M., T. Klopfenstein, G. A. Pfeifer, and R. A. Stock. 1989. Forage vs. grain finishing systems and the fate of increased weaning weight due to an increased level of milk. Nebraska Beef Rep. MP 54:29.

Lewis, J. M., T. J. Klopfenstein, G. A. Pfeiffer, and R. A. Stock. 1990. An economic evaluation of the differences between intensive and extensive beef production systems. J. Anim. Sci. 68:2506.

MacDonald, J. C., T. J. Klopfenstein, G. E. Erickson, C. N. Macken, J. D. Folmer, and M. P. Blackford. 2006. Sorting strategies for yearling cattle grown in an extensive forage utilization beef production system. Prof. Anim. Sci. 22:222.

MacDonald, J. C., T. J. Klopfenstein, G. E. Erickson, and K. J. Vander Pol. 2007. Changes in gain through the feeding period. Nebraska Beef Rep. MP 90:55.

Macken, C., G. Erickson, T. Klopfenstein, R. Stock, and S. Jaeger. 2003. Effects of corn pro- 
cessing method and crude protein levels with the inclusion of wet corn gluten feed on finishing steer performance. Nebraska Beef Rep. MP 80-A:25.

May, S. G., H. G. Dolezal, D. R. Gill, F. K. Ray, and D. S. Buchanan. 1992. Effects of days fed, carcass grade traits, and subcutaneous fat removal on postmortem muscle characteristics and beef palatability. J. Anim. Sci. 70:444.

Morris, S. E., J. C. MacDonald, D. C. Adams, T. J. Klopfenstein, R. L. Davis, and J. R. Teichert. 2006. Effect of supplemental dried distillers grains to steers grazing summer sandhill range. Nebraska Beef Rep. MP 88-A:30.

NRC. 1996. Nutrient requirements of beef cattle. Natl. Acad. Press, Washington, DC.

Reece, P. E., J. D. Volesky, and W. H. Schacht. 2001. Integrating management objectives and grazing strategies on semi-arid rangeland. Univ. of Nebraska Coop. Ext. EC01-158.

Sainz, R. D., and R. F. Vernazza Paganini. 2004. Effects of grazing and feeding periods on performance and carcass traits of beef steers. J. Anim. Sci. 82:292.

Saubidet, C. L., and L. S. Verde. 1976. Relationship between live weight, age, and dry matter intake for beef cattle after different levels of food restriction. Anim. Prod. 22:61.

Schoonmaker, J. P., S. C. Loerch, F. L. Fluharty, H. N. Zerby, and T. B. Turner. 2002. Effect of age at feedlot entry on performance and carcass characteristics of bulls and steers. J. Anim. Sci. 80:2247.

Scott, T., T. Klopfenstein, D. Shain, and M. Klemesrud. 1997. Wet corn gluten feed as a source of rumen degradable protein for finishing steers. Nebraska Beef Rep. MP 67-A:70.

Scott, T., T. Milton, T. Klopfenstein, and R. Stock. 2001. Corn processing method in finishing diets containing wet corn gluten feed. Nebraska Beef Rep. MP 76-A:59.

Scott, T., T. Milton, T. Mader, T. Klopfenstein, and R. Cooper. 1999. Effects of programmed gain on performance and carcass characteristics of calves. Nebraska Beef Rep. MP 71-A:46.

Shain, D. H., T. J. Klopfenstein, R. A. Stock, B. A. Vieselmeyer, and G. E. Erickson. 2005. Evaluation of grazing alternate summer and fall forages in extensive beef cattle production systems. Prof. Anim. Sci. 21:390.

Tatum, J. D., K. E. Belk, T. G. Field, J. A. Scanga, and G. C. Smith. 2006. Relative impor- tance of weight, quality grade, and yield grade as drivers of beef carcass value in two grid-pricing systems. Prof. Anim. Sci. 22:41.

Tedeschi, L. O., D. G. Fox, and P. J. Guiroy. 2004. A decision support system to improve individual cattle management. I. A mechanistic dynamic model for animal growth. Agric. Syst. 79:171.

Turgeon, O. A. 1984. Impact of high forage growing systems on finishing performance and compensatory growth. PhD Dissertation, University of Nebraska, Lincoln.

Vander Pol, K., J. Simon, G. Ericsson, T. Klopfenstein, E. Stanisiewski, and G. Hartnell. 2003. Feeding transgenic (Bt corn rootworm protected and roundup-ready) corn to feedlot cattle. Nebraska Beef Rep. MP 80-A:30.

Vieselmeyer, B. A. 1993. Production and economic interactions of extensive beef production systems. M.S. Thesis, University of Nebraska, Lincoln.

Vieselmeyer, B., T. Klopfenstein, R. Stock, R. Clark, R. Rasby, and D. Shain. 1995. Physiological and economic changes of beef cattle during finishing. Nebraska Beef Rep. MP 62-A:46. 